\title{
Senescent T cells within suppressive tumor microenvironments: emerging target for tumor immunotherapy
}

\author{
Xia Liu, Daniel F. Hoft, and Guangyong Peng \\ Division of Infectious Diseases, Allergy and Immunology and Department of Internal Medicine, Saint Louis University School of Medicine, St. Louis, Missouri, USA.
}

\begin{abstract}
The functional state of the preexisting T cells in the tumor microenvironment is a key determinant for effective antitumor immunity and immunotherapy. Increasing evidence suggests that immunosenescence is an important state of T cell dysfunction that is distinct from exhaustion, a key strategy used by malignant tumors to evade immune surveillance and sustain the suppressive tumor microenvironment. Here, we discuss the phenotypic and functional characteristics of senescent T cells and their role in human cancers. We also explore the possible mechanisms and signaling pathways responsible for induction of T cell senescence by malignant tumors, and then discuss potential strategies to prevent and/or reverse senescence in tumor-specific T cells. A better understanding of these critical issues should provide novel strategies to enhance cancer immunotherapy.
\end{abstract}

\section{Introduction}

Cell senescence has been well recognized over the past several decades as a biological process with stable cell cycle arrest in diploid cells. This phenomenon was initially described in primary human fibroblasts after limited passages in cell culture (1). It has been shown that senescence can occur in various types of cells and tissues under different physiological and pathological conditions, including in normal aging, cancer, and infectious diseases (2-8). Senescent cells have permanent cell cycle arrest, but remain viable and metabolically active and possess unique functions and regulatory mechanisms that distinguish them from quiescent and apoptotic cells (9-12). Senescence induction in tumor cells directly controls tumor initiation, stemness, development, and proliferation via regulation of many oncogenes and the key cell cycle checkpoint genes $(3,13-17)$. In addition, induction of tumor cells to become senescent cells is a potential anticancer therapeutic strategy $(13,18,19)$.

Recent studies have shown that senescence also occurs in human $\mathrm{T}$ cells, causing dysregulation of the immune system during the normal aging process $(12,20,21)$. Furthermore, accumulation of senescent $\mathrm{CD}^{+} \mathrm{T}$ cells has also been found in younger patients with chronic viral infections, as well as patients with certain types of cancers (22-28). To explore the mechanisms responsible for the induction of senescent $\mathrm{T}$ cells in cancer patients, more recent studies suggest that both naturally occurring regulatory $\mathrm{T}$ cells (nTregs) and tumor-derived Tregs can strongly suppress naive/effector T cells through the induction of responder $\mathrm{T}$ cell senescence (29-32). In addition, different types of tumor cells can directly convert normal

Conflict of interest: The authors have declared that no conflict of interest exists. Copyright: (5) 2020, American Society for Clinical Investigation.

Reference information: / Clin Invest. 2020;130(3):1073-1083.

https://doi.org/10.1172/JCl133679. immune cells into senescent $\mathrm{T}$ cells $(27,33,34)$. These senescent $\mathrm{T}$ cells have altered phenotypes and possess strong suppressive activity that can potently amplify immune suppression within the tumor microenvironment. Senescent $\mathrm{T}$ cells influence both immune cells and tumor cells through different potential molecular processes in the tumor microenvironment to promote tumor development and progression (discussed further in the following sections) $(27,29,30,33,34)$. In addition, in vivo studies using adoptive transfer immunotherapy melanoma models have demonstrated that human tumor cells or Tregs can induce senescence in adoptively transferred tumor-specific $\mathrm{T}$ cells and decrease their antitumor efficacy (31-33). Notably, the incidence and prevalence of cancer are also markedly increased with aging, which could be due to the increase of senescence in $\mathrm{T}$ cells in elderly individuals (35-37). The increasing evidence clearly suggests that prevention of senescence development in effector T cells is urgently needed for successful tumor immunity and immunotherapy.

In addition to senescence in $\mathrm{T}$ cells, $\mathrm{T}$ cell exhaustion is another important dysfunctional state in cancers $(38,39)$. Senescent and exhausted $\mathrm{T}$ cells both have defective effector functions for tumor immunity, but they have distinct phenotypes and distinct regulatory mechanisms underlying their development and impaired antitumor functions (29-31, 40, 41). Exhausted T cells highly express a panel of inhibitory receptors, including programmed cell death protein 1 (PD-1), cytotoxic T lymphocyte antigen-4 (CTLA-4), T cell immunoglobulin and mucin domain containing-3 (Tim-3), lymphocyte activation gene 3 (LAG-3), CD244 (2B4), and CD160 (42-47), and have been identified in patients with chronic viral infections and various types of cancers. Furthermore, exhausted T cells cannot proliferate, partially because of the PD-1-mediated suppression of $\mathrm{T}$ cell receptor (TCR) signaling (48). Exhausted T cells also display an impaired cytotoxic ability and production of effector cytokines such as 


\section{Table 1. Senescent T cells in the tumor microenvironments}

\begin{tabular}{|c|c|c|}
\hline Tumor type & Cell subsets & Sites \\
\hline Lung cancer & $\mathrm{CD}^{+}{ }^{+} \mathrm{CD} 28^{-}$ & $\begin{array}{l}\text { 1.) Peripheral blood. } \\
\text { 2.) Satellite lymph } \\
\text { nodes and tumor } \\
\text { lesions. }\end{array}$ \\
\hline Breast cancer & $\begin{array}{c}\mathrm{CD}^{+} \mathrm{CD} 28^{-}, \\
\mathrm{CD}^{+} \mathrm{CD} 28^{-} \\
\mathrm{CD} 28^{-} \mathrm{CD} 57^{+} \mathrm{CD} 8^{+}, \\
\mathrm{CD} 28^{-} \mathrm{CD}^{+}\end{array}$ & $\begin{array}{l}\text { 1.) Peripheral blood. } \\
\text { 2.) Sentinel nodes. } \\
\text { 3.) TILs. } \\
\text { 4.) Satellite lymph } \\
\text { nodes and tumor } \\
\text { lesions. }\end{array}$ \\
\hline
\end{tabular}

\begin{tabular}{|c|c|c|}
\hline Ovarian cancer & $\begin{array}{c}\mathrm{CD}^{+} \mathrm{CD}^{\mathrm{C}} \mathrm{3}^{+} \mathrm{CD}^{-} 8^{-} \\
\mathrm{CD}^{+} \mathrm{CD} 28^{-}\end{array}$ & $\begin{array}{l}\text { 1.) Malignant ascites. } \\
\text { 2.) Peripheral blood. } \\
\text { 3.) Satellite lymph } \\
\text { nodes and tumor } \\
\text { lesions. }\end{array}$ \\
\hline Head and neck cancer & $\mathrm{CD}^{+} \mathrm{CD} 28^{-}$ & $\begin{array}{l}\text { 1.) Peripheral blood. } \\
\text { 2.) Satellite lymph } \\
\text { nodes and tumor } \\
\text { lesions. }\end{array}$ \\
\hline
\end{tabular}

\begin{tabular}{|c|c|c|}
\hline Melanoma & $\begin{array}{c}\mathrm{CD}^{+} \mathrm{CD}^{2} 8^{-} \mathrm{CD} 27^{-} \\
\mathrm{CD}^{-} 8^{-} \mathrm{CD}^{+} \\
\mathrm{CD}^{+}{ }^{+} \mathrm{CD} 28^{-}\end{array}$ & $\begin{array}{l}\text { 1.) Peripheral blood. } \\
\text { 2.) TILs. } \\
\text { 3.) Satellite lymph } \\
\text { nodes and tumor } \\
\text { lesions. }\end{array}$ \\
\hline Multiple myeloma & $\begin{array}{c}\mathrm{CD}^{+} 7^{+} \mathrm{CD} 28^{-} \mathrm{CD}^{+} \\
\mathrm{KLRG}-1^{+} \mathrm{CD} 57^{+} \\
\mathrm{CD}^{+} 60^{+} \mathrm{CD} 28^{-}\end{array}$ & $\begin{array}{l}\text { 1.) Peripheral blood. } \\
\text { 2.) Bone marrow. }\end{array}$ \\
\hline
\end{tabular}

\begin{tabular}{|c|c|c|}
\hline Colorectal carcinomas & $\begin{array}{c}\mathrm{CD} 27^{+} \mathrm{CD} 28^{-} \mathrm{CD}^{+}, \\
\mathrm{CD} 27^{-} \mathrm{CD} 28^{-} \mathrm{CD} 8^{+} \\
\mathrm{CD}^{+} \mathrm{CD} 28^{-}\end{array}$ & $\begin{array}{l}\text { 1.) Peripheral blood } \\
\text { and TILs. } \\
\text { 2.) Satellite lymph } \\
\text { nodes and tumor } \\
\text { lesions. }\end{array}$ \\
\hline Endometrial carcinoma & $\mathrm{CD}^{+} \mathrm{CD}^{-} 8^{-}$ & $\begin{array}{l}\text { 1.) Peripheral blood. } \\
\text { 2.) TILs. }\end{array}$ \\
\hline $\begin{array}{l}\text { Cutaneous T cell } \\
\text { lymphoma }\end{array}$ & $\mathrm{CD}^{+} \mathrm{CD}^{-} 8^{-}$ & $\begin{array}{l}\text { 1.) Peripheral blood. } \\
\text { 2.) Skin infiltrates. }\end{array}$ \\
\hline $\begin{array}{l}\text { Others: gastric, } \\
\text { pancreatic, kidney, } \\
\text { thyroid, esophageal, } \\
\text { prostate, and }\end{array}$ & $\mathrm{CD}^{+} \mathrm{CD}^{+} 8^{-}$ & $\begin{array}{l}\text { 1.) Satellite lymph } \\
\text { nodes. } \\
\text { 2.) Peripheral blood. } \\
\text { 3.) Tumor lesions. }\end{array}$ \\
\hline
\end{tabular}

Key results

1.) Lung cancer patients show an expansion of the $C D 8^{+} C D 28^{-} T$ cell subset in the peripheral blood, and these cells express high levels of Foxp3 and release IL-10 and TGF- $\beta$, exhibiting as CD $8^{+}$Treg phenotypes.

2.) The percentage of $C D 8^{+} C D 28^{-}$Tregs is increased in NSCLC patients and correlated with the pathological stages and tumor burden in patients.

3.) $C D 8^{+} \mathrm{CD} 28-\mathrm{T}$ lymphocytes constantly present in human tumors and inhibit effector $\mathrm{T}$ cell proliferative and cytotoxic functions.

1.) Peripheral $\mathrm{CD} 8^{+} \mathrm{T}$ cells show downregulation of $\mathrm{CD} 28$ in cancer patients. 60

2.) The expression of $\mathrm{CD} 28$ and $\mathrm{CD} 3-\zeta$ in sentinel lymph nodes of breast cancer patients is decreased. 28

3.) The proportion of $\mathrm{CD} 28^{-} \mathrm{CD} 57^{+} \mathrm{CD} 8^{+} \mathrm{T}$ cells remains high among patients with cancer even after 61 chemotherapy.

4.) Progressive elevated levels of $C D 8^{+} C D 28^{-}$suppressor T cells in metastatic breast cancer patients 62 are a significant predictor for outcomes.

5.) $\mathrm{CD}^{+}$TILs derived from patients downregulate CD28 expression.

6.) $\mathrm{CD}^{+} \mathrm{CD} 28^{-} \mathrm{T}$ lymphocytes with suppressive activities exist in human tumors.

1.) Patients with advanced serous ovarian cancer have elevated frequencies of $C D 8^{+} C D 103^{+} C D 28^{-} T$ cells.

2.) The levels of $C D 8^{+} \mathrm{CD} 28^{-} \mathrm{T}$ cells are high in patients and are correlated with the tumor burden and 58 pathological stages.

3.) $\mathrm{CD}^{+} \mathrm{CD} 28^{-} \mathrm{T}$ cells in tumors suppress effector $\mathrm{T}$ cell proliferative and cytotoxic functions.

1.) In patients with head and neck cancer, the frequency of the effector $\operatorname{CD} 8^{+} \mathrm{CD} 28^{-} \mathrm{T}$ cell population is increased while that of naive $\mathrm{CD}^{+} \mathrm{CD}^{+} 8^{+} \mathrm{CD} 45 \mathrm{RO} 0^{-}$cells is decreased; and $\mathrm{CD}^{+} \mathrm{CD} 28^{-} \mathrm{T}$ cells are the apoptosis-sensitive subset and are terminally differentiated effector cells.

2.) $C D 8^{+} \mathrm{CD} 28^{-} \mathrm{T}$ cells in tumors suppress effector $\mathrm{T}$ cell proliferative and cytotoxic functions.

1.) $C D 28-C D 27-C D 8^{+} T$ cell subset is expanded in patients, which represents terminally differentiated effector cells expressing CD244 and high levels of perforin.

2.) TILs derived from patients downregulate $\mathrm{CD} 28$ expression.

3.) $\mathrm{CD}^{+} \mathrm{CD}^{-} 8^{-} \mathrm{T}$ cells in tumors suppress effector T cell proliferative and cytotoxic functions.

53

57

53

23

1.) T cells in MM patients display features of senescence at the tumor site, expressing CD57 but lacking CD28.

2.) Dysfunctional clonal T cells in MM exhibit a senescence phenotype, $K L R G-1^{+} C D 57^{+} C D 160^{+} C D 28^{-}$, but with low PD-1 and CTLA-4 expression.

1.) $C D 8^{+}$TILs isolated from colorectal cancer patients are mainly $C D 27^{+} C D 28^{-}$or $C D 27^{-} C D 28^{-}$cells, which have low levels of perforin.

2.) $\mathrm{CD}^{+} \mathrm{CD} 28^{-} \mathrm{T}$ cell populations exist in human tumors and suppress effector $\mathrm{T}$ cells. 53

The CD8 ${ }^{+} \mathrm{T}$ cells from PBLs and TILs express CD28, CD45RA, and CD45R0, but most tumor-infiltrating $\mathrm{CD}^{+} \mathrm{T}$ cells are CD28-CD45RA-CD45RO+CCR7-' suggesting a good terminal differentiation.

Increased percentages of CD8+CD28- suppressor lymphocytes in peripheral blood and skin infiltrates are correlated with advanced disease in patients with cutaneous T cell lymphomas. CD8 ${ }^{+}$CD28- $T$ cell populations exist in human tumors and suppress effector T cells.

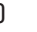

(1)

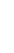
(n) (

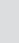

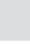

(2)

neuroendocrine cancers

NSCLC, non-small cell lung cancer; PBL, peripheral blood lymphocyte; TIL, tumor-infiltrating lymphocyte.

IL-2, TNF, and IFN- $\gamma$ (47). Unlike exhausted T cells, senescent $\mathrm{T}$ cells do not express increased levels of exhaustion-associated inhibitory molecules, but highly express senescence-associated $\beta$-galactosidase (SA- $\beta$-gal) and dramatically downregulate the costimulatory molecules CD27 and CD28 (7, 29-31, 49). Notably, senescent $\mathrm{T}$ cells have a unique senescence-associated secretory phenotype (SASP), producing high amounts of proinflammatory cytokines, which also is distinct from exhausted $\mathrm{T}$ cells (discussed in the following sections) $(29-31,33)$. Current clinical trials using immune checkpoint blockade to interfere with CTLA-4 and/or PD-1/programmed cell death ligand 1 (PD-L1) have shown promising benefits for certain types of cancer patients, but overall success rates remain limited (50-52), suggesting that $\mathrm{T}$ cell exhaustion is not fully responsible for impaired antitumor function. Therefore, improved understanding of the molecular mechanisms involved in the induction and functional regulations of senescent $\mathrm{T}$ cells within the tumor microenvironment should lead to novel immunotherapies. 
Table 2. Characteristics of senescent T cells

\begin{tabular}{|c|c|c|c|}
\hline & Markers & Molecular features & References \\
\hline The specific marker & SA- $\beta$-gal & High expression & $29,30,49$ \\
\hline Costimulatory molecules & CD27, CD28 & Downregulation or loss of expression & $29-31$ \\
\hline Other associated molecules & Tim-3, CD57, KLRG-1 & High expression & $67-69,71$ \\
\hline Cell cycle arrest & $\begin{array}{l}\text { Proliferation; } \mathrm{p} 16, \mathrm{p} 21 \\
\text { and } \mathrm{p} 53\end{array}$ & $\begin{array}{l}\text { Display cell cycle arrest and cannot proliferate with T cell receptor stimulation; } \\
\text { high expression of p16, p21, and p53 }\end{array}$ & $29,30,33$ \\
\hline Metabolic activation & SASP & $\begin{array}{l}\text { Metabolically active; secrete high amounts of proinflammatory cytokines } \\
\text { (IL-2, IL-6, IL-8, TNF, and IFN- } \gamma \text { ) and suppressive cytokines IL-10 and TCF- } \beta\end{array}$ & $\begin{array}{l}29,30,33,72 \\
73,76,77\end{array}$ \\
\hline Unique transcriptional profile & Transcriptional profile & $\begin{array}{c}\text { Unique transcriptional profile distinct from that of anergic T cells, exhausted T cells, } \\
\text { and quiescent terminally differentiated T cells }\end{array}$ & $75-80$ \\
\hline DNA damage & ATM, $\gamma \mathrm{H} 2 \mathrm{AX}, \mathrm{p} 53 \mathrm{BP}$ & Upregulation of DNA damage response molecules & 31,32 \\
\hline Functional alterations & $\begin{array}{l}\text { Killing abilities; negative } \\
\text { regulatory functions }\end{array}$ & Defective killing abilities; negative regulatory functions; potent suppressive activity & $25,26,74$ \\
\hline
\end{tabular}

ATM, ataxia-telangiectasia mutated; $\gamma \mathrm{H} 2 \mathrm{AX}$, phosphorylated H2AX; KLRG-1, killer cell lectin-like receptor subfamily G member 1; p53BP, p53-binding protein; SA- $\beta$-gal, senescence-associated $\beta$-galactosidase; SASP, senescence-associated secretory phenotype; Tim-3, T cell immunoglobulin and mucin domain containing-3.

\section{T cell senescence is typical in suppressive tumor microenvironments}

Substantial accumulation of senescent $\mathrm{CD} 8^{+} \mathrm{T}$ cells has been found among tumor-infiltrating lymphocytes (TILs) that are associated with various types of cancers, including lung $(22,53,54)$, colorectal (55), endometrial $(56)$, ovarian $(57,58)$, lymphoma (59), and breast cancers $(28,60-62)$, melanoma $(33,63)$, and multiple myeloma $(\mathrm{MM})(64,65)$, as well as with tumor metastases $(22,53)$. Recent studies have demonstrated that tumor-derived Tregs can induce $\mathrm{T}$ cell senescence (29-32). Furthermore, multiple types of tumor cells, including breast cancer, melanoma, colon cancer, prostate cancer, ovarian cancer, and head and neck cancer cells, can also directly induce $\mathrm{T}$ cell senescence $(33,34)$. These studies explain why senescent $\mathrm{T}$ cells accumulate within suppressive tumor microenvironments. Given that senescent T cells do not mediate antitumor activities, these observations strongly suggest that induction of $\mathrm{T}$ cell senescence is a key strategy used by malignant tumors to evade immune surveillance (refs. 12, 23, 29, 30, 33, 34 and Table 1).

\section{Characteristics of senescent T cells}

Senescence is an independent cell stage with unique phenotypes and functions. Unlike the extensive studies already focused on cell senescence in fibroblasts and tumors, very limited information is known about senescence in T cells (12). In recent studies of senescent $\mathrm{T}$ cells that develop during the normal aging process and in patients with chronic infections and cancers, senescent $\mathrm{T}$ cells display several specific characteristics (refs. 12, 22-30, and Table 2): (a) Senescent T cells highly express SA- $\beta$-gal $(29,30,49)$. (b) Senescent $\mathrm{T}$ cells dramatically downregulate the costimulatory molecules CD27 and CD28 $(7,29,66)$ and highly express other senescenceassociated markers, including Tim-3, CD57, and killer cell lectin-like receptor subfamily G member 1 (KLRG-1) (67-71). (c) Senescent T cells upregulate cell cycle regulatory genes including p16, p21, and p53; are in a state of cell cycle arrest; and do not proliferate after TCR stimulation $(29,30,33)$. (d) Senescent T cells remain metabolically active with a unique SASP $(72,73)$, producing high amounts of proinflammatory cytokines such as IL-2, IL-6, IL-8, TNF, and IFN- $\gamma$, as well as the suppressive cytokines IL-10 and TGF- $\beta(29,30,33)$. (e) Senescent $\mathrm{CD}^{+} \mathrm{T}$ cells have defective killing abilities due to the loss of perforin and granzyme, or defects in granule exocytosis $(7,26)$. (f) Senescent $\mathrm{CD} 8^{+} \mathrm{T}$ cells have negative regulatory functions that reduce the protective effects of immunization, as well as prolong the survival of allografts $(25,74)$. (g) Senescent $\mathrm{T}$ cells themselves become suppressive cells mediating potent inhibition of proliferation and effector functions of other immune cells $(29-31,33)$. (h) Senescent $\mathrm{T}$ cells develop a unique transcriptional profile distinct from that of anergic T cells, exhausted $\mathrm{T}$ cells, and quiescent terminally differentiated $\mathrm{T}$ cells $\left(31,75^{-80}\right)$.

\section{Functional roles of senescent T cells in tumorigenesis}

Increasing evidence strongly suggests that senescent $\mathrm{T}$ cells are critical mediators and amplifiers of immune suppression within the suppressive tumor microenvironment, promoting tumor development and progression (refs. 27, 29, 30, 33, 34 and Figure 1). A better understanding of the functional role of senescent $\mathrm{T}$ cells in tumor immunity is important for the development of novel cancer immunotherapeutic strategies.

$\mathrm{T}$ cell senescence is an important dysfunctional state with impaired antitumor capacities (12). In tumor microenvironments, senescent $\mathrm{T}$ cells are converted/differentiated from effector $\mathrm{T}$ cells and/or naive T cells. Once they become senescent, these cells are unable to respond to tumor antigen stimulation and recognition because of the downregulation of costimulatory molecules such as CD27 and CD28, the upregulation of inhibitory molecules including Tim-3 (7, 29, 67-71), and decreased production of the effector molecules perforin and granzyme $(7,26)$. Senescent $\mathrm{T}$ cells also actively suppress other immune cells within the tumor microenvironment. Senescent T cells induced by Tregs and tumor cells themselves become potent suppressor cells, directly inhibiting different types of immune cells, including Th1, Th17, CD8 ${ }^{+} \mathrm{T}$ cells, and DCs (29-31, 33). Furthermore, senescent $\mathrm{T}$ cells also secrete large amounts of IL-10 and TGF- $\beta 1$, inducing adaptive Tregs and increasing the immunosuppressive tumor microenvironments (29-31, 33). 


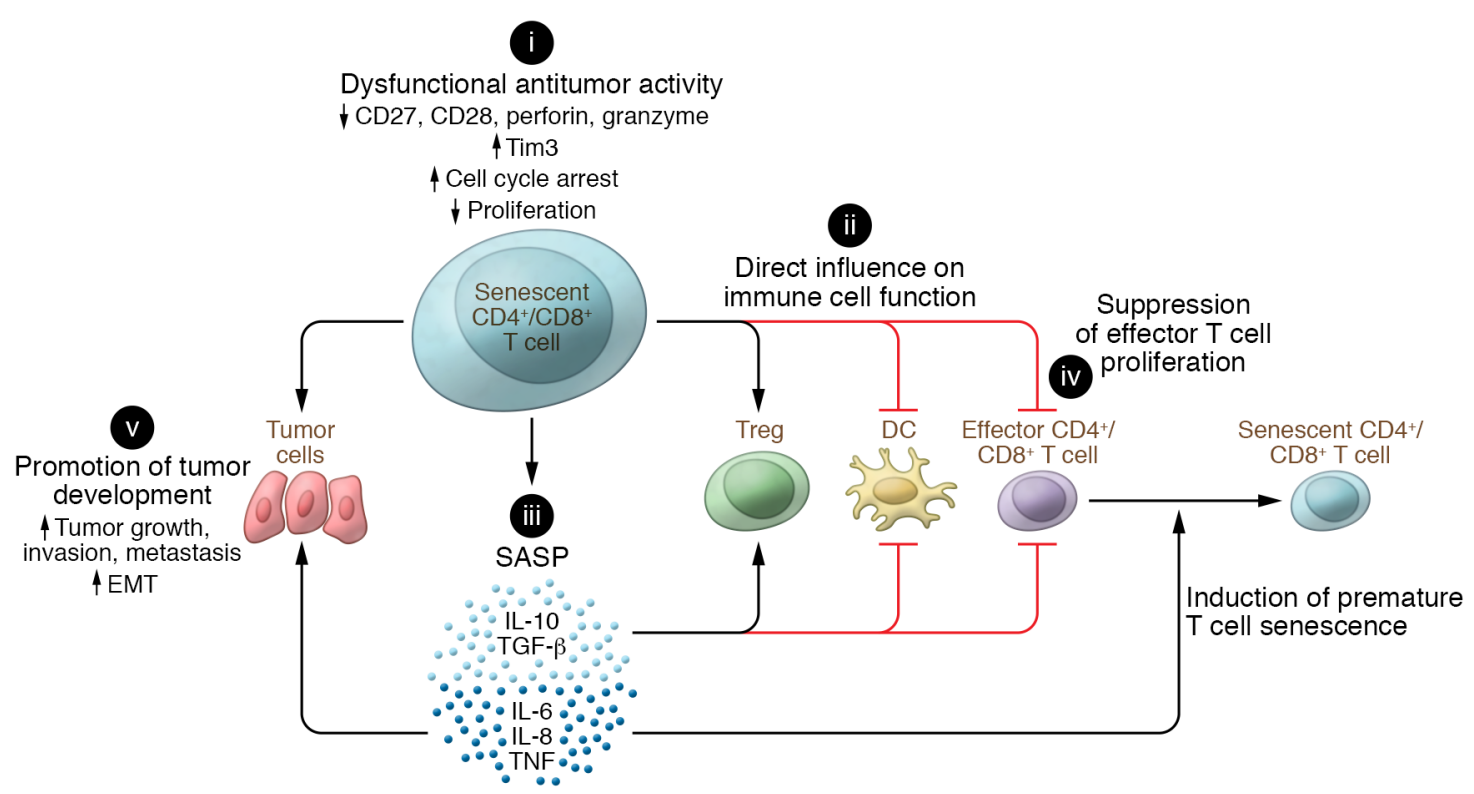

Figure 1. Effects of senescent T cells on tumorigenesis and cancer progression. (i) Senescent T cells have unique phenotypes with impaired antitumor activities. They downregulate the costimulatory molecules CD27 and CD28 as well as the effector molecules perforin and granzyme, and decrease proliferation, but promote cell cycle arrest and expression of molecules that inhibit proliferation. (ii) Senescent T cells can actively influence other immune cells within the tumor microenvironment. In addition to inducing adaptive Tregs, they can become potent suppressor cells themselves, performing direct inhibition on DCs and effector T cells. (iii) Senescent T cells have a unique SASP, secreting large amounts of cytokines that can induce premature senescence in T cells (IL-6, IL-8, TNF) and suppress effector immune cells (IL-10, TGF- $\beta$ ), as well as disrupt normal mammary differentiation and promote malignant phenotypes and tumor cell growth. (iv) Senescent T cells with potent suppressive activity can directly suppress effector T cell proliferation and function. (v) Senescent T cells can promote tumor growth, invasion, metastasis, and epithelial-to-mesenchyme transition via SASP or cell-cell direct contact.

In contrast to the functional defects in antitumor immunity, senescent $\mathrm{T}$ cells are metabolically active and have a unique SASP, which influences both immune cells and tumor cells in the tumor microenvironment. Recent studies clearly indicate that senescent $\mathrm{T}$ cells induced by tumor cells and Tregs can secrete large amounts of the cytokines IL-6, IL-8, and TNF $(29,30,33,34)$. These proinflammatory cytokines are critical inducers of premature senescence via autocrine or paracrine mechanisms $(73,81-83)$, which could induce more senescent $\mathrm{T}$ cells within suppressive tumor microenvironments. Furthermore, SASP can induce expansion of FoxP3 ${ }^{+}$Tregs and $\mathrm{CD} 11 \mathrm{~b}^{+} \mathrm{Ly} 6 \mathrm{G}^{\text {hi }}$ cell populations and enhance their suppressive activity on tumor immunity $(84,85)$. In addition to establishment of a suppressive tumor microenvironment, the senescent cell-mediated SASP can directly favor malignant tumor progression through various effects, including disruption of normal mammary differentiation (86), inducing malignant transformation $(87,88)$, enhancing proliferation and invasiveness of neoplastic epithelial cells, promoting epithelial-mesenchymal transition, and increasing aggressiveness of metastatic cancers (Figure 1 and refs. 84, 86, 88-90). Sustained tumor growth can, in turn, eventually overwhelm the host's ability to eliminate cancer cells, tipping the balance in favor of malignant cancer progression.

\section{Metabolic alterations drive $T$ cell senescence within tumor microenvironments}

Although increased senescent $\mathrm{T}$ cells have been observed in various types of cancer patients, the mechanisms and factors responsible for the induction of $\mathrm{T}$ cell senescence in the tumor microenvironment are still under investigation (Figure 2). It is clear that replicative senescence (telomere-dependent senescence), which occurs due to telomere shortening and/or dysfunctional telomerase that trigger a classical DNA-damage response $(91,92)$, contributes to aging and age-related pathologies in vivo (93). Furthermore, replicative senescence in $\mathrm{T}$ cells $\left(\mathrm{CD} 8^{+} \mathrm{CD} 28^{\text {null }} \mathrm{T}\right.$ cells) also occurs in patients with chronic infections, such as cytomegalovirus, Epstein-Barr virus, hepatitis C virus, and HIV infections (4-7). Repeated antigenic stimulation during chronic inflammation and persistent infection (viral, bacterial, or parasitic) induces extensive pathogen-specific $\mathrm{T}$ cell proliferation and prolonged activation, resulting in loss of telomerase activity, telomere shortening and/or telomere erosion, and replicative senescence (94, 95). Recent studies have demonstrated that TILs have short telomeres, suggesting that reintroduction of telomerase into $\mathrm{T}$ cells could be a novel strategy for tumor immunotherapy (96-98). However, a potential causal relationship between chronic exposure to tumor-specific antigens and accumulated senescent $\mathrm{T}$ cells within the tumor microenvironment remains unclear.

Increasing evidence indicates that development of $\mathrm{T}$ cell senescence in cancer patients is induced by tumor microenvironmental factors and extrinsic forms of stress, such as oxidative stress, DNA damage, activation of certain oncogenes, and production of inflammatory cytokines and chemokines (10, 99101). Metabolic reprogramming is one of the important causes of $\mathrm{T}$ cell premature senescence in the tumor microenvironment. Tumor-derived Tregs can promote the conversion of responder $\mathrm{T}$ cells into senescent T cells $(29-31,33,34)$. Mechanistically, Tregs exhibit heightened glucose uptake, increased glycolysis, and accelerated glucose consumption, which reduce glucose available 


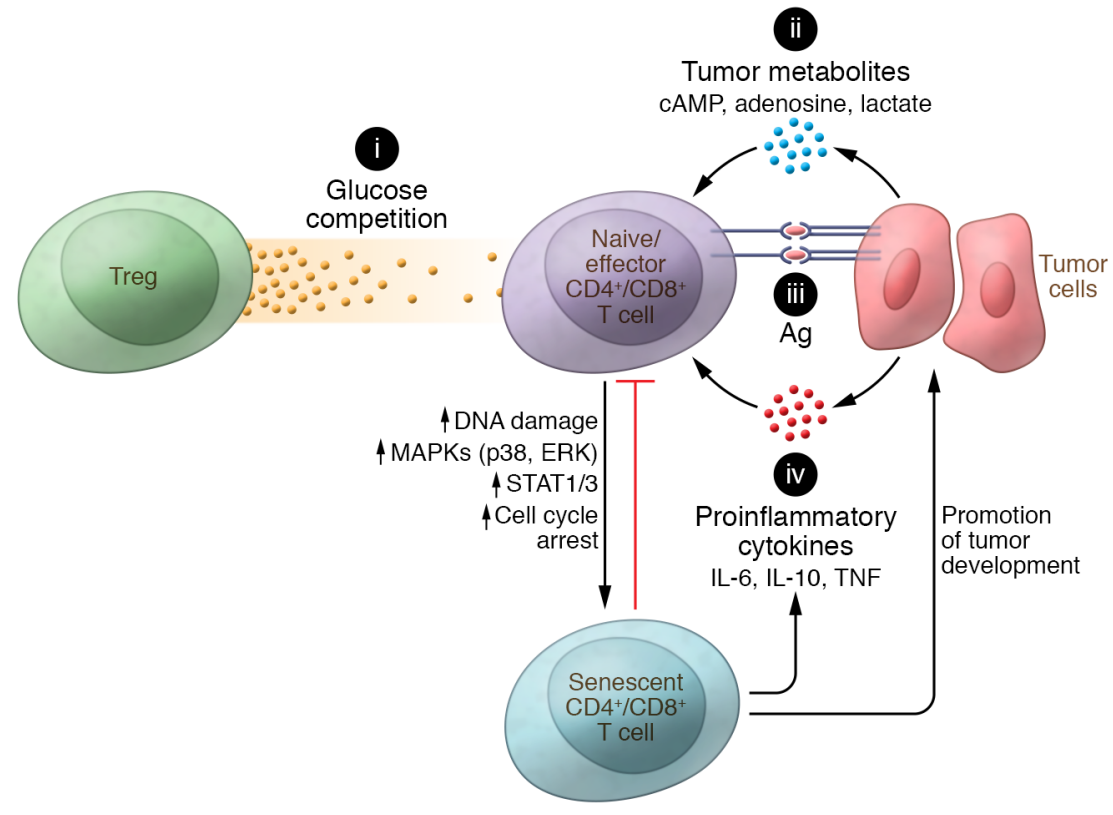

Figure 2. Potential signaling/mechanisms responsible for the development of senescent $T$ cells within the suppressive tumor microenvironment. (i) Tregs' accelerated glucose consumption creates glucose competition in the tumor microenvironment, which can induce cell senescence in responder T cells during their crosstalk. (ii) Accumulation of metabolic end products, including cAMP, adenosine, and lactate, in the tumor microenvironment suppresses effector $\mathrm{T}$ cells and/or promotes induction of T cell senescence. (iii) Continuous and repeated stimulation from tumor antigens in T cells may induce loss of telomerase activity and result in replicative senescence of T cells. (iv) Tumor-derived microenvironmental inflammatory cytokines enhance tumor proliferation, inflammation, angiogenesis, and metastasis, and can also promote the development of senescent T cells. All these signaling pathways may potentially initiate the ATMassociated DNA damage response and activate MAPK and STAT1/3 signaling, resulting in T cell senescence in the tumor microenvironment. for effector $\mathrm{T}$ cells. These interactions initiate activation of the AMP-activated protein kinase (AMPK) in responder $\mathrm{T}$ cells and eventually result in the DNA damage response associated with the nuclear kinase ataxia-telangiectasia mutated protein (ATM), and senescence in T cells $(31,32)$. It has been shown that low concentrations of glucose alone can significantly induce both $\mathrm{CD} 4^{+}$and $\mathrm{CD}^{+} \mathrm{T}$ cell senescence (31). In contrast, high concentrations of glucose $(25 \mathrm{mM})$ dramatically prevent responder $\mathrm{T}$ cell senescence mediated by nTregs and tumor-derived Tregs $(31,32)$. Activation of AMPK, an important nutrient and energy sensor that is activated by reactive oxygen species and DNA-damaging agents, is the key step for T cell senescence (102-104). Activated AMPK can regulate cell cycle progression through increased phosphorylation of $\mathrm{p} 53$ and accumulation of $\mathrm{p} 21^{\mathrm{WAF} 1}$ and $\mathrm{p} 27$ expression $(105,106)$. A recent study has shown that AMPK is activated in CD27 ${ }^{-} \mathrm{CD} 28$ senescent $\mathrm{T}$ cells, leading to autophosphorylation of $\mathrm{p} 38$ and inhibition of telomerase activity, as well as reduced $\mathrm{T}$ cell proliferation and expression of key components of the TCR signalosome (107). Furthermore, AMPK agonists can induce senescence characteristics in nonsenescent $\mathrm{T}$ cells (107). Interestingly, tumor-infiltrating Tregs are highly activated and proliferative, and are not prone to senescence in the suppressive tumor microenvironment (31, $32,108,109)$. As discussed above, heightened glucose and lipid metabolism distinguishes both nTregs and tumor-derived Tregs from effector T cells $(31,32)$. Therefore, Tregs' energy demands, a combination of glycolysis and fatty acid synthesis and oxidation, confer a metabolic advantage that preferentially promotes proliferation and expansion in the tumor microenvironment (108). In addition, recent studies showed that Treg division and suppressive function are unaffected in the metabolically abnormal tumor microenvironment with low glucose and high lactate (109). Specifically, the transcription factor FoxP3 reprograms metabolism in Tregs, driving Treg resistance to the intracellular NAD depletion that results from the oxidation of L-lactate to pyruvate by lactate dehydrogenase; in contrast, intracellular NAD depletion dramatically impairs effector T cell function and proliferation (109). In addition to tumor-derived Tregs, tumor cells themselves display heightened glucose and glutamine consumption, resulting in the depletion of nutrients and the accumulation of metabolites (110112). More evidence suggested that tumor cells and TILs both compete for glucose within the suppressive tumor microenvironment, leading to cancer progression (113-115).

In addition to the direct competition for nutrients with effector $\mathrm{T}$ cells, accumulated metabolic end products, including cyclic adenosine monophosphate (cAMP), IDO, adenosine, and lactate, in the tumor microenvironment produced by tumor cells and Tregs are important inducers of $\mathrm{T}$ cell senescence $(12,32,110-$ $112,116)$. cAMP is a potent inhibitor of effective tumor-specific $\mathrm{T}$ cells within the tumor microenvironment $(111,117)$. Furthermore, cAMP is also involved in Treg-mediated suppression (118). Studies have demonstrated that different types of tumor cells can directly induce conversion from naive/effector $\mathrm{T}$ cells into senescent $\mathrm{T}$ cells with potent suppressive activity $(33,34)$. High concentrations of endogenous cAMP exist in both tumor cells and tumor-induced senescent $\mathrm{T}$ cells and have been mechanistically implicated as responsible for the induction of $\mathrm{T}$ cell senescence. Tumor cells can transfer cAMP to targeted naive/effector T cells via gap junctions, resulting in markedly increased cAMP levels in senescent $\mathrm{T}$ cells. cAMP-induced $\mathrm{T}$ cell senescence is mechanistically dependent on the triggering of the ATM-associated DNA damage response in T cells $(33,119,120)$. Unlike direct transfer of cAMP between cells, adenosine triggers immunosuppressive signaling via intracellular cAMP-elevating $\mathrm{A}_{2 \mathrm{~A}}$ adenosine receptors on T cells (121). Chronic exposure of $\mathrm{CD}^{+} \mathrm{T}$ cells to exogenous adenosine can accelerate the process of cell senescence, causing reductions in overall proliferative potential and telomerase activity, and blunted IL-2 gene transcription (122). In addition, the loss of CD28 expression by senescent $\mathrm{T}$ cells is accelerated as a result of suppression of the CD28 promoter by adenosine-induced increases of caspase- 3 (122). Notably, recent studies suggest that tumor-derived exosomes carrying numerous cargos, such as RNA and DNA, lipids, proteins, and metabolites, are also critical to regulate both tumor 
cells and immune cells and to maintain a hypoxic and suppressive tumor microenvironment (123-126). These exosomes directly suppress antitumor activity and memory formation in effector T cells, as well as promote expansion and activation of Tregs (124, 127, 128). However, whether the tumor-derived exosomes also involve the development of $\mathrm{T}$ cell senescence in the tumor microenvironment remains unknown. A better understanding of the mechanistic links between tumor immunosuppression, hypoxia, metabolic dysregulation, and induction of $\mathrm{T}$ cell senescence should lead to novel strategies for cancer immunotherapy.

\section{MAPK and STAT signaling critically control T cell senescence}

It is well established that mitogen-activated protein kinase (MAPK) signaling is involved in controlling cellular senescence. However, the importance of MAPK signaling in T cell senescence was not explored until recently $(12,29,31,129,130)$. ERK1/2 and p38 activation can induce p21-dependent $G_{1}$ cell cycle arrest as well as activate both the $\mathrm{p} 53$ and the $\mathrm{pRb} / \mathrm{p} 16$ growth arrest pathways $(131,132)$. In addition, MAPK signaling pathways control oncogenic Ras-induced senescence (133-135). Furthermore, p38 MAPK is involved in regulation of many SASP cytokines and chemokines in senescent cells $(136,137)$. Constitutive p38 MAPK activation is sufficient to induce SASP, while inhibition of p38 MAPK signaling markedly reduces secretion of most SASP factors (138). More recent studies have shown that the CD27-CD28 subset of $\mathrm{CD} 4^{+} \mathrm{T}$ cells exhibited elevated phosphorylation of $\mathrm{p} 38$, and that activation of $\mathrm{p} 38$ by AMPK and scaffold TAB1 induces human $\mathrm{T}$ cell senescence (129). Furthermore, the sestrin-dependent ERK-JNK-p38 MAPK activation complex controls T cell senescence (130). To identify the signaling pathways responsible for $\mathrm{T}$ cell senescence in the suppressive tumor microenvironment, recent studies have demonstrated that the cell cycle regulatory molecules p53, p21, and p16 are significantly increased in senescent $\mathrm{T}$ cells induced by both Tregs and tumor cells (29, 31, 33). Furthermore, ERK1/2 and p38 are selectively phosphorylated and activated during $\mathrm{T}$ cell senescence processes required for induction of responder $\mathrm{T}$ cell senescence mediated by human Tregs. In addition, STAT1 and STAT3 signaling mediates cellular senescence induced by $\mathrm{H}_{2} \mathrm{O}_{2}$, stress, and radiation (90, 139, 140). STAT1 and STAT3 signaling also involves T cell senescence mediated by both nTregs and tumor-derived Tregs (31). Collectively, ATM-associated DNA damage response, MAPK signaling, and STAT1 and STAT3 signaling cooperate to control T cell differentiation and development of senescence during the crosstalk with Tregs (Figure 2 and ref. 31). The studies discussed here and below identify the unique molecular signaling that controls and maintains $\mathrm{T}$ cell senescence in the tumor microenvironment, which should provide insights for the development of therapies designed to block $\mathrm{T}$ cell senescence and restore effector functions for tumor immunotherapy.

\section{Senescence reversal and functional rejuvenation of tumor-specific T cells}

All of these studies strongly indicate that malignant tumors use the induction of $\mathrm{T}$ cell senescence, which impairs antitumor capacities, as a strategy to escape the immune system (27, 29-34).
Therefore, developing strategies to prevent the generation of senescence and control the fate and function of tumor-specific $\mathrm{T}$ cells is critical for antitumor immunity.

Blocking molecular signaling important for senescent $T$ cell differentiation. Inhibition of key signaling pathways controlling senescence induction in tumor-specific T cells could be a critical checkpoint for effective and enhanced antitumor immunity. Growth arrest in fibroblasts that are at an early stage of senescence can be reversed by blocking key cell cycle regulatory genes (p53, p38, and p21) and/or DNA damage response proteins (ATM or the cell cycle arrest protein CHK2) $(92,141-144)$. These studies have already provided critical insights for how to control the development of cell senescence. Recent studies have demonstrated that ATM signaling, MAPKs ERK1/2 and p38 signaling, and STAT1/STAT3 signaling are selectively activated during senescent $\mathrm{T}$ cell development induced by human Tregs and tumor cells (29, 31-33). Furthermore, blockage of ATM, ERK1/2, and p38 as well as STAT signaling pathways can considerably prevent the induction of $\mathrm{T}$ cell senescence in vitro and in vivo in animal models $(29-31,33,34)$.

MAPK signaling is also critical for T cell activation and effector functions $(144,145)$. Therefore, selection of optimal MAPK inhibitors for preventing senescence induction without affecting proliferation and effector function in tumor-reactive $\mathrm{T}$ cells is urgently needed (12). MAPK inhibitors have been widely used in clinical trials for the treatment of melanoma patients (146-148), and some selective MAPK inhibitors have already shown significant enhancement of $\mathrm{T}$ cell recognition of melanoma without affecting lymphocyte function $(149,150)$. ATM inhibitors also have been used in clinical trials for cancer patients $(151,152)$. Those selective MAPK and ATM inhibitors already available for clinical use should be priority candidates for exploring the efficacy of $\mathrm{T}$ cell senescence inhibition in cancer patients $(149,150$, $153,154)$. In addition, recent studies have suggested that AMPK can trigger autophosphorylation of p38 and metabolic regulation of human $\mathrm{T}$ cell senescence during aging and interaction with Tregs $(31,107)$. Therefore, knockdown of AMPK by shRNA results in enhanced telomerase activity and proliferation of senescent T cells (107). Furthermore, sestrins bind to and coordinate ERK, JNK, and p38 MAPK activation in CD27-CD28- CD $4^{+} \mathrm{T}$ cells, and sestrin deficiency enhances $\mathrm{T}$ cell responsiveness and expansion in vivo during aging (130). Identification of more specific signaling pathways responsible for the generation of senescent $\mathrm{T}$ cells in the tumor microenvironment should lead to effective therapeutic targets for cancer immunotherapy.

Reprogramming Treg and tumor metabolism via TLR8 signaling. Both nTregs and tumor-derived Tregs can strongly suppress naive/effector $\mathrm{T}$ cells through the induction of responder $\mathrm{T}$ cell senescence, which mechanistically depends on glucose competition with responder $\mathrm{T}$ cells during their interaction $(29,30,32)$. Toll-like receptors (TLRs) are very important for regulating Treg function $(32,155-158)$. TLR8 signaling reverses the suppressive functions of tumor-derived $\mathrm{CD} 4^{+}, \mathrm{CD}^{+}$, and $\gamma \delta$ Tregs, resulting in enhanced antitumor immunity mediated by tumor-specific $\mathrm{CD}^{+} \mathrm{T}$ cells in adoptive transfer tumor models (29, 30, 156, 157). Furthermore, TLR 8 signaling in human Tregs can prevent their induction of senescence in responder T cells and DCs and can reverse the suppressor function of senescent $\mathrm{T}$ cells $(29,30)$. 
Cellular energy metabolism also directs T cell survival, proliferation, and function (159-162), and both glucose and lipid metabolism is required for Treg suppression $(32,163)$. Recent studies suggest that TLR signaling directly regulates energy metabolism in immune cells, including in Tregs (164-166). TLR1 and TLR2 signaling activation in mouse Tregs increases Treg glycolysis and proliferation and reduces their suppressive capacity (167). Unlike TLR1/2 signaling in murine Tregs, TLR8 signaling activation can suppress both glucose uptake and transport as well as glycolysis in human Tregs, but does not alter glucose metabolism in naive and effector $\mathrm{T}$ cells, resulting in prevention of responder $\mathrm{T}$ cell senescence $(31,32)$. In addition to tumor-derived Tregs, tumor cells convert normal immune cells into senescent $\mathrm{T}$ cells via the metabolite cAMP, resulting in impaired antitumor immunity (27, $33,34)$. Increasing evidence suggests that TLRs directly regulate metabolism, affecting tumor behavior and function in melanoma, prostate cancer, head and neck carcinoma, and breast cancer (33, $34,158,168)$. Human TLR8 signaling also directly targets multiple types of tumor cells and modulates the levels of endogenous metabolite cAMP in tumor cells, preventing their ability to induce $\mathrm{T}$ cell senescence $(33,34)$. Importantly, these in vitro studies were further confirmed in vivo for tumor immunotherapy, showing that TLR8 signaling can enhance antitumor immunity by preventing Treg- and tumor-induced senescence in tumor-specific effector $\mathrm{T}$ cells in vivo in the adoptive transfer therapy melanoma models $(32,33,156,157)$. These studies collectively indicate that human TLR8 signaling can reprogram glucose metabolism in both Tregs and tumor cells, resulting in suppression of their abilities to induce senescence in effector T cells. Therefore, TLR8 ligands could be effective tumor immunotherapeutic agents and/or adjuvants for tumor immunotherapy.

\section{Concluding remarks and future perspectives}

Current immunotherapies, including immune checkpoint blockade therapy and adoptive $\mathrm{T}$ cell therapy, have led to promising results in certain types of cancer patients, but the overall effective rates remain limited and vary among tumor types $(51,169)$. Exploration of alternative novel strategies targeting more specific checkpoint molecules or interrupting tolerogenic pathways is urgently needed. One of the key determinants of therapeutic efficacy is the functional state of the transferred/preexisting $\mathrm{T}$ cells in the suppressive tumor microenvironment $(170,171)$. Increasing evidence suggests that development of $\mathrm{T}$ cell senescence is a general feature and an important $\mathrm{T}$ cell dysfunctional state in the tumor microenvironment, which should be an emerging target for tumor immunotherapy (29-33). Therefore, preventing tumor-specific $\mathrm{T}$ cell senescence and rejuvenating effector $\mathrm{T}$ cell functions could become successful cancer immunotherapeutic strategies.

Cellular senescence has been recognized as a biological process over the past 50 years. However, the role and function of senescent $\mathrm{T}$ cells in tumor immunity remain unclear. Precisely dissecting the molecular mechanisms responsible for the development of $\mathrm{T}$ cell senescence will not only facilitate a better understanding of how malignant tumors escape immunity and sustain a suppressive tumor microenvironment, but also should provide emerging targets for tumor immunotherapy. Recent studies have identified MAPK and STAT3 signaling pathways as critical for controlling the development of T cell senescence $(29,31)$. Furthermore, TLR8 signaling can reprogram metabolism in Tregs and tumor cells, reverse their suppressive effects, and prevent induction of $\mathrm{T}$ cell senescence mediated by tumors and Tregs $(32,33)$. Therefore, inhibition of MAPK signaling and/or TLR8 signaling activation should be effective strategies to control tumor-specific $\mathrm{T}$ cell senescence and dysfunction for tumor immunotherapy in the future.

It is now well recognized that the immune system can have both immune surveillance and tumor promotion effects during cancer development $(172,173)$. Furthermore, the functional role and subsets of $\mathrm{T}$ cells in the tumor microenvironment are dynamic during tumor progression (174). More efforts are needed to elucidate the alterations and plasticity among different states of $\mathrm{T}$ cells in the immunoediting processes within the tumor microenvironment during cancer progression. In addition, different types of tumors are highly heterogeneous, associated with distinct escape mechanisms and clinical outcomes within $\mathrm{T}$ cell-inflamed and -noninflamed tumor microenvironments $(175,176)$. T cell exhaustion and senescence are important dysfunctional states in cancers that are utilized by malignant tumors to escape antitumor immunity (29-31, 38-41). Therefore, a comprehensive understanding of the dynamic states and functions of $\mathrm{T}$ cells, including senescent and/or exhausted $\mathrm{T}$ cells in diverse tumor microenvironments, is essential for the development of novel therapeutic strategies to treat cancer patients. Recently, advancements in single-cell-based technologies and tissue imaging have made this possible $(8,177,178)$.

Increasing evidence indicates that targeting $\mathrm{T}$ cell senescence is an emerging concept for enhancing tumor immunity and immunotherapy. Although great progress has been made in this specific area of cancer research, gaps in our understanding of the role of senescent $T$ cells in different types of cancer patients remain. First, although induction of $\mathrm{T}$ cell senescence is a general feature within the suppressive tumor microenvironment, the causative mechanisms responsible for the senescent $\mathrm{T}$ cell development mediated by malignant tumors remain unclear. Cellular energy metabolism directs the fates and functions of T cells (159-162). However, the metabolic alterations involved in the induction and functions of these senescent immune cells in the tumor microenvironment are unknown. Therefore, improved understanding of metabolic regulations involved in the generation and development of senescent $\mathrm{T}$ cells mediated by different types of malignant tumors is urgently needed. These studies should lead to potential therapeutic targets for metabolic reprogramming to block senescence in tumor-specific $\mathrm{T}$ cells for cancer immunotherapy. Second, it is now recognized that senescent $\mathrm{T}$ cells are not exhausted and/or anergic $\mathrm{T}$ cells (31). Although senescent $\mathrm{T}$ cells are defective in antitumor immune functions, they are active and possess a unique SASP phenotype. SASP compositions include cytokines, lipids, metabolites, and extracellular vesicles and are complicated and highly heterogeneous, depending on duration of $\mathrm{T}$ cell senescence in the tumor progression $(8,179)$. However, the functional fractions of senescent T cell-derived SASP and its role in regulating effector immune cell functions and tumor development within the tumor microenvironment are unknown. Thus, further characterization of the unique molecular signatures and functional roles of SASP derived from senescent $T$ cells during tumor development is needed to develop an effective and specific antitumor immunothera- 
py. In addition, current clinical trials targeting CTLA-4 or PD-1/ PD-L1 have yielded only limited success rates $(51,169)$. More recent studies have shown that $\mathrm{PD}-1$-mediated suppression of $\mathrm{T}$ cell function results from dephosphorylation and inactivation of CD28 (180), and the CD28/B7 costimulatory pathway is required for effective anti-PD-1 therapy in cancer and chronic viral infection (181). Efficacy of anti-PD-1 therapy in cancer patients is related to $\mathrm{PD}-1^{+} \mathrm{CD}^{+} \mathrm{T}$ cell proliferation and the activation and expression of CD28 in $\mathrm{PD}-1^{+} \mathrm{CD} 8^{+} \mathrm{T}$ cells $(181)$. One of the important characteristics of senescent $\mathrm{T}$ cells is downregulation or loss of CD28 expression (29-31). Therefore, it is difficult to activate senescent $\mathrm{T}$ cells in the tumor microenvironment.

Given that accumulated senescent $\mathrm{T}$ cells exist in cancer patients, the causative relationship between $\mathrm{T}$ cell senescence and unresponsiveness to current immunotherapies is another important but challenging issue that needs to be investigated. Compre- hensively and precisely understanding these critical issues will provide insights for the development of promising clinical treatments against cancers in the future.

\section{Acknowledgments}

Because of space limitations, the authors apologize that they cannot cite all relevant references in this research area. This work was partially supported by grants from the American Cancer Society (RSG-10-160-01-LIB to GP), the Melanoma Research Alliance (to GP), and the NIH (AI097852, AI094478, and CA184379 to GP).

Address correspondence to: Guangyong Peng, Department of Internal Medicine, Saint Louis University School of Medicine, 1100 S Grand Boulevard, St. Louis, Missouri 63104, USA. Phone: 314.977.9064; Email: guangyong.peng@health.slu.edu.
1. Hayflick L. The limited in vitro lifetime of human diploid cell strains. Exp Cell Res. 1965;37:614-636.

2. Calcinotto A, Kohli J, Zagato E, Pellegrini

L, Demaria M, Alimonti A. Cellular senescence: aging, cancer, and injury. Physiol Rev. 2019;99(2):1047-1078.

3. Lee S, Schmitt CA. The dynamic nature of senescence in cancer. Nat Cell Biol. 2019;21(1):94-101.

4. Khan N, et al. Cytomegalovirus seropositivity drives the CD8 T cell repertoire toward greater clonality in healthy elderly individuals. J Immunol.2002;169(4):1984-1992.

5. Appay V, et al. Memory CD8 ${ }^{+} \mathrm{T}$ cells vary in differentiation phenotype in different persistent virus infections. Nat Med. 2002;8(4):379-385.

6. Tomiyama H, Oka S, Ogg GS, Ida S, McMichael AJ, Takiguchi M. Expansion of HIV-1-specific CD28- CD45RA- CD8 ${ }^{+}$T cells in chronically HIV-1-infected individuals. AIDS. 2000;14(13):2049-2051.

7. Vallejo AN. CD28 extinction in human T cells: altered functions and the program of T-cell senescence. Immunol Rev. 2005;205:158-169.

8. Gorgoulis V, et al. Cellular senescence: defining a path forward. Cell. 2019;179(4):813-827.

9. Shelton DN, Chang E, Whittier PS, Choi D, Funk WD. Microarray analysis of replicative senescence. Curr Biol. 1999;9(17):939-945.

10. Campisi J, d'Adda di Fagagna F. Cellular senescence: when bad things happen to good cells. Nat Rev Mol Cell Biol. 2007;8(9):729-740.

11. Zhang B, et al. The senescence-associated secretory phenotype is potentiated by feedforward regulatory mechanisms involving Zscan 4 and TAK1. Nat Commun. 2018;9(1):1723.

12. Liu X, Peng G. T cell senescence and tumor immunotherapy. In: Fulop T, Francheschi C, Hirokawa K, Pawalec G, eds. Handbook of Immunosenescence: Basic Understanding and Clinical Implications. Basel, Switzerland: Springer Nature; 2019;1-24

13. Wright WE, Pereira-Smith OM, Shay JW. Reversible cellular senescence: implications for immortalization of normal human diploid fibroblasts. Mol Cell Biol. 1989;9(7):3088-3092.

14. Ventura A, et al. Restoration of p53 function leads to tumour regression in vivo. Nature.
2007;445(7128):661-665.

15. Collado M, Serrano M. Senescence in tumours: evidence from mice and humans. Nat Rev Cancer. 2010;10(1):51-57.

16. Braig M, et al. Oncogene-induced senescence as an initial barrier in lymphoma development. Nature. 2005;436(7051):660-665

17. Milanovic M, et al. Senescence-associated reprogramming promotes cancer stemness. Nature. 2018;553(7686):96-100.

18. Nardella C, Clohessy JG, Alimonti A, Pandolfi PP. Pro-senescence therapy for cancer treatment. Nat Rev Cancer. 2011;11(7):503-511.

19. Qin S, Schulte BA, Wang GY. Role of senescence induction in cancer treatment. World J Clin Oncol. 2018;9(8):180-187.

20. Effros RB, Dagarag M, Spaulding C, Man J. The role of CD8+ T-cell replicative senescence in human aging. Immunol Rev. 2005;205:147-157.

21. Weng NP, Akbar AN, Goronzy J. CD28(-) T cells: their role in the age-associated decline of immune function. Trends Immunol. 2009;30(7):306-312.

22. Meloni F, et al. Foxp3 expressing $\mathrm{CD} 4^{+} \mathrm{CD} 25^{+}$and $\mathrm{CD} 8^{+} \mathrm{CD} 28^{-} \mathrm{T}$ regulatory cells in the peripheral blood of patients with lung cancer and pleural mesothelioma. Hum Immunol. 2006;67(1-2):1-12.

23. Tsukishiro T, Donnenberg AD, Whiteside TL. Rapid turnover of the CD8(+)CD28(-) T-cell subset of effector cells in the circulation of patients with head and neck cancer. Cancer Immunol Immunother. 2003;52(10):599-607.

24. Wolfram RM, et al. Defective antigen presentation resulting from impaired expression of costimulatory molecules in breast cancer. Int J Cancer. 2000;88(2):239-244.

25. Chen WH, Kozlovsky BF, Effros RB, Grubeck-Loebenstein B, Edelman R, Sztein MB. Vaccination in the elderly: an immunological perspective. Trends Immunol. 2009;30(7):351-359.

26. Appay V, et al. HIV-specific CD8(+) T cells produce antiviral cytokines but are impaired in cytolytic function. J Exp Med. 2000;192(1):63-75.

27. Montes CL, et al. Tumor-induced senescent $T$ cells with suppressor function: a potential form of tumor immune evasion. Cancer Res. 2008;68(3):870-879.
28. Schüle JM, Bergkvist L, Håkansson L, Gustafsson B, Håkansson A. CD28 expression in sentinel node biopsies from breast cancer patients in comparison with CD3-zeta chain expression. J Transl Med. 2004;2(1):45.

29. Ye J, et al. Human regulatory T cells induce T-lymphocyte senescence. Blood. 2012;120(10):2021-2031.

30 . Ye J, et al. Tumor-derived $\gamma \delta$ regulatory T cells suppress innate and adaptive immunity through the induction of immunosenescence. J Immunol. 2013;190(5):2403-2414.

31. Liu X, et al. Regulatory T cells trigger effector T cell DNA damage and senescence caused by metabolic competition. Nat Commun. 2018;9(1):249.

32. Li L, et al. TLR8-mediated metabolic control of human Treg function: a mechanistic target for cancer immunotherapy. Cell Metab. 2019;29(1):103-123.e5.

33. Ye J, et al. TLR8 signaling enhances tumor immunity by preventing tumor-induced T-cell senescence. EMBO Mol Med. 2014;6(10):1294-1311.

34. Ye J, Peng G. Controlling T cell senescence in the tumor microenvironment for tumor immunotherapy. Oncoimmunology. 2015;4(3):e994398.

35. van Deursen JM. The role of senescent cells in ageing. Nature. 2014;509(7501):439-446.

36. Fulop T, Kotb R, Fortin CF, Pawelec G, de Angelis F, Larbi A. Potential role of immunosenescence in cancer development. Ann N Y Acad Sci. 2010;1197:158-165.

37. Chou JP, Effros RB. T cell replicative senescence in human aging. Curr Pharm Des. 2013;19(9):1680-1698.

38. Wherry EJ. T cell exhaustion. Nat Immunol. 2011;12(6):492-499.

39. Schietinger A, Greenberg PD. Tolerance and exhaustion: defining mechanisms of T cell dysfunction. Trends Immunol. 2014;35(2):51-60.

40. Reiser J, Banerjee A. Effector, memory, and dysfunctional CD8(+) T cell fates in the antitumor immune response. JImmunol Res. 2016;2016:8941260.

41. Akbar AN, Henson SM. Are senescence and exhaustion intertwined or unrelated processes that compromise immunity? Nat Rev Immunol. 2011;11(4):289-295. 
42. Wherry EJ, et al. Molecular signature of CD8+ $\mathrm{T}$ cell exhaustion during chronic viral infection. Immunity. 2007;27(4):670-684

43. Blackburn SD, et al. Coregulation of $\mathrm{CD}^{+} \mathrm{T}$ cell exhaustion by multiple inhibitory receptors during chronic viral infection. Nat Immunol. 2009;10(1):29-37.

44. Baitsch L, et al. Exhaustion of tumor-specific $\mathrm{CD}^{+} \mathrm{T}$ cells in metastases from melanoma patients. JClin Invest. 2011;121(6):2350-2360.

45. Zhou Q, et al. Coexpression of Tim-3 and PD-1 identifies a $\mathrm{CD} 8^{+} \mathrm{T}$-cell exhaustion phenotype in mice with disseminated acute myelogenous leukemia. Blood. 2011;117(17):4501-4510.

46. Fourcade J, et al. Upregulation of Tim-3 and PD-1 expression is associated with tumor antigen-specific $\mathrm{CD} 8^{+} \mathrm{T}$ cell dysfunction in melanoma patients. JExp Med. 2010;207(10):2175-2186.

47. Jiang Y, Li Y, Zhu B. T-cell exhaustion in the tumor microenvironment. Cell Death Dis. 2015;6:e1792.

48. Sheppard KA, et al. PD-1 inhibits T-cell receptor induced phosphorylation of the ZAP70/CD3 signalosome and downstream signaling to PKC $\theta$. FEBS Lett. 2004;574(1-3):37-41.

49. Dimri GP, et al. A biomarker that identifies senescent human cells in culture and in aging skin in vivo. Proc Natl Acad Sci U S A. 1995;92(20):9363-9367.

50. Topalian SL, Drake CG, Pardoll DM. Immune checkpoint blockade: a common denominator approach to cancer therapy. Cancer Cell. 2015;27(4):450-461.

51. Sharma P, Allison JP. Immune checkpoint targeting in cancer therapy: toward combination strategies with curative potential. Cell. 2015;161(2):205-214.

52. Pardoll DM. The blockade of immune checkpoints in cancer immunotherapy. Nat Rev Cancer 2012;12(4):252-264.

53. Filaci $\mathrm{G}$, et al. $\mathrm{CD} 8^{+} \mathrm{CD} 28^{-} \mathrm{T}$ regulatory lymphocytes inhibiting $\mathrm{T}$ cell proliferative and cytotoxic functions infiltrate human cancers. J Immunol. 2007;179(7):4323-4334.

54. Chen C, et al. Changes of $\mathrm{CD} 4{ }^{+} \mathrm{CD} 25^{+} \mathrm{FOXP}^{+}$ and $\mathrm{CD}^{+}{ }^{+} \mathrm{CD} 28^{-}$regulatory $\mathrm{T}$ cells in non-small cell lung cancer patients undergoing surgery. Int Immunopharmacol. 2014;18(2):255-261.

55. Ye SW, et al. Ex-vivo analysis of $\mathrm{CD} 8^{+} \mathrm{T}$ cells infiltrating colorectal tumors identifies a major effector-memory subset with low perforin content. JClin Immunol. 2006;26(5):447-456.

56. Chang WC, Li CH, Huang SC, Chang DY, Chou LY, Sheu BC. Clinical significance of regulatory $\mathrm{T}$ cells and $\mathrm{CD} 8^{+}$effector populations in patients with human endometrial carcinoma. Cancer. 2010;116(24):5777-5788

57. Webb JR, et al. Profound elevation of $\mathrm{CD}^{+} \mathrm{T}$ cells expressing the intraepithelial lymphocyte marker $\mathrm{CD} 103(\alpha \mathrm{E} / \beta 7$ Integrin) in high-grade serous ovarian cancer. Gynecol Oncol. 2010;118(3):228-236.

58 . Wu M, et al. Changes in regulatory $\mathrm{T}$ cells in patients with ovarian cancer undergoing surgery: preliminary results. Int Immunopharmacol. 2017;47:244-250.

59. Urbaniak-Kujda D, et al. Increased percentage of $\mathrm{CD}^{+} \mathrm{CD} 28^{-}$suppressor lymphocytes in peripheral blood and skin infiltrates correlates with advanced disease in patients with cutaneous T-cell lymphomas. Postepy Hig Med Dosw (Online). 2009;63:355-359.

60. Gruber IV, El Yousfi S, Dürr-Störzer S, Wallwiener D, Solomayer EF, Fehm T. Down-regulation of CD28, TCR-zeta ( $\zeta)$ and up-regulation of FAS in peripheral cytotoxic T-cells of primary breast cancer patients. Anticancer Res. 2008;28(2A):779-784.

61. Onyema OO, et al. Chemotherapy-induced changes and immunosenescence of $\mathrm{CD} 8^{+} \mathrm{T}$-cells in patients with breast cancer. Anticancer Res. 2015;35(3):1481-1489.

62. Song G, et al. Elevated level of peripheral CD8(+) CD28(-) T lymphocytes are an independent predictor of progression-free survival in patients with metastatic breast cancer during the course of chemotherapy. Cancer Immunol Immunother. 2013;62(6):1123-1130.

63. Casado JG, et al. CD8 T cells expressing NK associated receptors are increased in melanoma patients and display an effector phenotype. Cancer Immunol Immunother. 2005;54(12):1162-1171.

64. Zelle-Rieser C, et al. $\mathrm{T}$ cells in multiple myeloma display features of exhaustion and senescence at the tumor site. J Hematol Oncol. 2016;9(1):116.

65. Suen $\mathrm{H}$, et al. Multiple myeloma causes clonal T-cell immunosenescence: identification of potential novel targets for promoting tumour immunity and implications for checkpoint blockade. Leukemia. 2016;30(8):1716-1724.

66. Effros RB, et al. Decline in CD28 ${ }^{+} \mathrm{T}$ cells in centenarians and in long-term $\mathrm{T}$ cell cultures: a possible cause for both in vivo and in vitro immunosenescence. Exp Gerontol. 1994;29(6):601-609.

67. Li H, et al. Tim-3/galectin-9 signaling pathway mediates T-cell dysfunction and predicts poor prognosis in patients with hepatitis B virus-associated hepatocellular carcinoma. Hepatology. 2012;56(4):1342-1351.

68. Brenchley JM, et al. Expression of CD57 defines replicative senescence and antigen-induced apoptotic death of $\mathrm{CD} 8^{+} \mathrm{T}$ cells. Blood. 2003;101(7):2711-2720.

69. Heffner M, Fearon DT. Loss of T cell receptor-induced Bmi-1 in the KLRG1(+) senescent CD8(+) T lymphocyte. Proc Natl Acad Sci U S A. 2007;104(33):13414-13419.

70. Voehringer D, Blaser C, Brawand P, Raulet DH, Hanke T, Pircher H. Viral infections induce abundant numbers of senescent CD8 T cells. JImmunol. 2001;167(9):4838-4843.

71. Huang $X$, et al. Lymphoma endothelium preferentially expresses Tim- 3 and facilitates the progression of lymphoma by mediating immune evasion. J Exp Med.2010;207(3):505-520.

72. Coppé JP, et al. Senescence-associated secretory phenotypes reveal cell-nonautonomous functions of oncogenic RAS and the p53 tumor suppressor. PLoS Biol. 2008;6(12):2853-2868.

73. Kuilman T, et al. Oncogene-induced senescence relayed by an interleukin-dependent inflammatory network. Cell. 2008;133(6):1019-1031.

74. Cortesini R, LeMaoult J, Ciubotariu R, Cortesini NS. CD $8^{+} \mathrm{CD} 28^{-} \mathrm{T}$ suppressor cells and the induction of antigen-specific, antigen-presenting cell-mediated suppression of Th reactivity. Immunol Rev. 2001;182:201-206.
75. Macián F, Im SH, García-Cózar FJ, Rao A. T-cell anergy. Curr Opin Immunol. 2004;16(2):209-216.

76. Wells AD. New insights into the molecular basis of T cell anergy: anergy factors, avoidance sensors, and epigenetic imprinting. J Immunol. 2009;182(12):7331-7341.

77. Wherry EJ, Kurachi M. Molecular and cellular insights into T cell exhaustion. Nat Rev Immunol. 2015;15(8):486-499.

78. Chang BD, et al. Effects of p21Waf1/Cip1/Sdi1 on cellular gene expression: implications for carcinogenesis, senescence, and age-related diseases. Proc Natl Acad Sci U S A. 2000;97(8):4291-4296.

79. Faraonio R, et al. A set of miRNAs participates in the cellular senescence program in human diploid fibroblasts. Cell Death Differ. 2012;19(4):713-721.

80. Seroogy CM, Fathman CG. T-cell anergy: from phenotype to genotype and back. Immunol Res. 2003;28(3):255-264.

81. Wajapeyee N, Serra RW, Zhu X, Mahalingam $\mathrm{M}$, Green MR. Oncogenic BRAF induces senescence and apoptosis through pathways mediated by the secreted protein IGFBP7. Cell. 2008;132(3):363-374.

82. Kortlever RM, Higgins PJ, Bernards R. Plasminogen activator inhibitor- 1 is a critical downstream target of $\mathrm{p} 53$ in the induction of replicative senescence. Nat Cell Biol. 2006;8(8):877-884.

83. Acosta JC, et al. Chemokine signaling via the CXCR2 receptor reinforces senescence. Cell. 2008;133(6):1006-1018.

84. Sun Y, Coppé JP, Lam EW. Cellular senescence: the sought or the unwanted? Trends Mol Med. 2018;24(10):871-885.

85. Ruhland MK, et al. Stromal senescence establishes an immunosuppressive microenvironment that drives tumorigenesis. Nat Commun 2016;7:11762

86. Parrinello S, Coppe JP, Krtolica A, Campisi J. Stromal-epithelial interactions in aging and cancer: senescent fibroblasts alter epithelial cell differentiation. JCell Sci. 2005;118(pt 3):485-496.

87. Wang T, et al. Senescent carcinoma-associated fibroblasts upregulate IL8 to enhance prometastatic phenotypes. Mol Cancer Res. 2017;15(1):3-14.

88. Bavik C, Coleman I, Dean JP, Knudsen B, Plymate $\mathrm{S}$, Nelson PS. The gene expression program of prostate fibroblast senescence modulates neoplastic epithelial cell proliferation through paracrine mechanisms. Cancer Res. 2006;66(2):794-802.

89. Laberge RM, Awad P, Campisi J, Desprez PY. Epithelial-mesenchymal transition induced by senescent fibroblasts. Cancer Microenviron. 2012;5(1):39-44.

90. Canino C, et al. SASP mediates chemoresistance and tumor-initiating-activity of mesothelioma cells. Oncogene. 2012;31(26):3148-3163.

91. d'Adda di Fagagna F, et al. A DNA damage checkpoint response in telomere-initiated senescence. Nature. 2003;426(6963):194-198.

92. Herbig U, Jobling WA, Chen BP, Chen DJ, Sedivy JM. Telomere shortening triggers senescence of human cells through a pathway involving ATM, p53, and p21(CIP1), but not p16(INK4a). Mol Cell. 2004;14(4):501-513.

93. Itahana K, Campisi J, Dimri GP. Mechanisms of cellular senescence in human and mouse cells. Biogerontology. 2004;5(1):1-10. 
94. Andrews NP, Fujii H, Goronzy JJ, Weyand CM. Telomeres and immunological diseases of aging. Gerontology. 2010;56(4):390-403.

95. Blackburn EH. Telomeres and telomerase: their mechanisms of action and the effects of altering their functions. FEBS Lett. 2005;579(4):859-862.

96. Dagarag M, Evazyan T, Rao N, Effros RB. Genetic manipulation of telomerase in HIV-specific $\mathrm{CD}^{+} \mathrm{T}$ cells: enhanced antiviral functions accompany the increased proliferative potential and telomere length stabilization. J Immunol. 2004;173(10):6303-6311.

97. Barsov EV. Telomerase and primary T cells: biology and immortalization for adoptive immunotherapy. Immunotherapy. 2011;3(3):407-421.

98. Shen X, et al. Persistence of tumor infiltrating lymphocytes in adoptive immunotherapy correlates with telomere length. JImmunother. 2007;30(1):123-129.

99. Lleonart ME, Artero-Castro A, Kondoh H. Senescence induction; a possible cancer therapy. $\mathrm{Mol}$ Cancer. 2009;8:3.

100.Acosta JC, et al. Chemokine signaling via the CXCR2 receptor reinforces senescence. Cell. 2008;133(6):1006-1018.

101.Kuilman T, et al. Oncogene-induced senescence relayed by an interleukin-dependent inflammatory network. Cell. 2008;133(6):1019-1031.

102. Hawley SA, et al. Use of cells expressing gamma subunit variants to identify diverse mechanisms of AMPK activation. Cell Metab. 2010;11(6):554-565.

103. Zmijewski JW, Banerjee S, Bae H, Friggeri A, Lazarowski ER, Abraham E. Exposure to hydrogen peroxide induces oxidation and activation of AMP-activated protein kinase. J Biol Chem. 2010;285(43):33154-33164.

104.Fu X, Wan S, Lyu YL, Liu LF, Qi H. Etoposide induces ATM-dependent mitochondrial biogenesis through AMPK activation. PLoS One. 2008;3(4):e2009.

105. Imamura K, Ogura T, Kishimoto A, Kaminishi $\mathrm{M}$, Esumi H. Cell cycle regulation via p53 phosphorylation by a 5 -AMP activated protein kinase activator, 5-aminoimidazole- 4-carboxamide-1-beta-D-ribofuranoside, in a human hepatocellular carcinoma cell line. Biochem Biophys Res Commun. 2001;287(2):562-567.

106.Liang J, et al. The energy sensing LKB1-AMPK pathway regulates $\mathrm{p} 27$ (kip1) phosphorylation mediating the decision to enter autophagy or apoptosis. Nat Cell Biol. 2007;9(2):218-224.

107. Lanna A, Henson SM, Escors D, Akbar AN. The kinase p38 activated by the metabolic regulator AMPK and scaffold TAB1 drives the senescence of human T cells. Nat Immunol 2014;15(10):965-972.

108. Pacella I, et al. Fatty acid metabolism complements glycolysis in the selective regulatory $\mathrm{T}$ cell expansion during tumor growth. Proc Natl Acad Sci U S A. 2018;115(28):E6546-E6555.

109. Angelin A, et al. Foxp3 reprograms T cell metabolism to function in low-glucose, high-lactate environments. Cell Metab. 2017;25(6):1282-1293.e7.

110. Gordan JD, Thompson CB, Simon MC. HIF and c-Myc: sibling rivals for control of cancer cell metabolism and proliferation. Cancer Cell. 2007;12(2):108-113.
111. Sitkovsky MV, Kjaergaard J, Lukashev D, Ohta A. Hypoxia-adenosinergic immunosuppression: tumor protection by $\mathrm{T}$ regulatory cells and cancerous tissue hypoxia. Clin Cancer Res. 2008;14(19):5947-5952.

112. Croci DO, Zacarías Fluck MF, Rico MJ, Mata P, Rabinovich GA, Scharovsky OG. Dynamic cross-talk between tumor and immune cells in orchestrating the immunosuppressive network at the tumor microenvironment. Cancer Immunol Immunother. 2007;56(11):1687-1700.

113. Chang $\mathrm{CH}$, et al. Metabolic competition in the tumor microenvironment is a driver of cancer progression. Cell. 2015;162(6):1229-1241.

114. Sukumar M, Roychoudhuri R, Restifo NP. Nutrient competition: a new axis of tumor immunosuppression. Cell. 2015;162(6):1206-1208.

115. Cascone T, et al. Increased tumor glycolysis char acterizes immune resistance to adoptive $\mathrm{T}$ cell therapy. Cell Metab. 2018;27(5):977-987.e4.

116. Dang CV, Semenza GL. Oncogenic alterations of metabolism. Trends Biochem Sci. 1999;24(2):68-72.

117. Vang T, et al. Activation of the $\mathrm{COOH}$-terminal Src kinase (Csk) by cAMP-dependent protein kinase inhibits signaling through the $\mathrm{T}$ cell receptor. JExp Med. 2001;193(4):497-507.

118. Bopp T, et al. Cyclic adenosine monophosphate is a key component of regulatory T cell-mediated suppression. J Exp Med. 2007;204(6):1303-1310.

119. Van Nguyen T, Puebla-Osorio N, Pang H, Dujka ME, Zhu C. DNA damage-induced cellular senescence is sufficient to suppress tumorigenesis: a mouse model. J Exp Med. 2007;204(6):1453-1461.

120. Rodier F, et al. Persistent DNA damage signalling triggers senescence-associated inflammatory cytokine secretion. Nat Cell Biol. 2009;11(8):973-979.

121. Sitkovsky MV, Kjaergaard J, Lukashev D, Ohta A. Hypoxia-adenosinergic immunosuppression: tumor protection by $\mathrm{T}$ regulatory cells and cancerous tissue hypoxia. Clin Cancer Res. 2008;14(19):5947-5952.

122. Parish ST, Kim S, Sekhon RK, Wu JE, Kawakatsu Y, Effros RB. Adenosine deaminase modulation of telomerase activity and replicative senescence in human CD8 T lymphocytes. JImmunol. 2010;184(6):2847-2854.

123. Peinado H, et al. Melanoma exosomes educate bone marrow progenitor cells toward a pro-metastatic phenotype through MET. Nat Med. 2012;18(6):883-891.

124. Poggio M, et al. Suppression of exosomal PD-L1 induces systemic anti-tumor immunity and memory. Cell. 2019;177(2):414-427.e13.

125. Meng W, Hao Y, He C, Li L, Zhu G. Exosome-orchestrated hypoxic tumor microenvironment. Mol Cancer. 2019;18(1):57.

126. Othman N, Jamal R, Abu N. Cancer-derived exosomes as effectors of key inflammation-related players. Front Immunol. 2019;10:2103.

127. Muller L, et al. Human tumor-derived exosomes (TEX) regulate Treg functions via cell surface signaling rather than uptake mechanisms. Oncoimmunology. 2017;6(8):e1261243.

128.Szajnik M, Czystowska M, Szczepanski MJ, Mandapathil M, Whiteside TL. Tumor-derived microvesicles induce, expand and up-regulate biological activities of human regulatory $\mathrm{T}$ cells
(Treg). PLoS One. 2010;5(7):e11469.

129. Lanna A, Henson SM, Escors D, Akbar AN. The kinase $\mathrm{p} 38$ activated by the metabolic regulator AMPK and scaffold TAB1 drives the senescence of human T cells. Nat Immunol. 2014;15(10):965-972.

130. Lanna A, et al. A sestrin-dependent Erk-Jnk-p38 MAPK activation complex inhibits immunity during aging. Nat Immunol. 2017;18(3):354-363.

131. Todd DE, et al. ERK1/2 and $\mathrm{p} 38$ cooperate to induce a p21CIP1-dependent G1 cell cycle arrest. Oncogene. 2004;23(19):3284-3295.

132. Iwasa H, Han J, Ishikawa F. Mitogen-activated protein kinase $\mathrm{p} 38$ defines the common senescence-signalling pathway. Genes Cells. 2003;8(2):131-144.

133. Kwong J, Hong L, Liao R, Deng Q, Han J, Sun P. p38alpha and p38gamma mediate oncogenic ras-induced senescence through differential mechanisms. J Biol Chem. 2009;284(17):11237-11246.

134. Li H, Wang W, Liu X, Paulson KE, Yee AS, Zhang X. Transcriptional factor HBP1 targets P16(INK4A), upregulating its expression and consequently is involved in Ras-induced premature senescence. Oncogene. 2010;29(36):5083-5094.

135. Wang W, et al. Sequential activation of the MEK-extracellular signal-regulated kinase and MKK3/6-p38 mitogen-activated protein kinase pathways mediates oncogenic ras-induced premature senescence. Mol Cell Biol. 2002;22(10):3389-3403.

136. Freund A, Orjalo AV, Desprez PY, Campisi J. Inflammatory networks during cellular senescence: causes and consequences. Trends Mol Med. 2010;16(5):238-246.

137. Coppé JP, Desprez PY, Krtolica A, Campisi J. The senescence-associated secretory phenotype: the dark side of tumor suppression. Annu Rev Pathol. 2010;5:99-118.

138. Freund A, Patil CK, Campisi J. p38MAPK is a novel DNA damage response-independent regulator of the senescence-associated secretory phenotype. EMBO J. 2011;30(8):1536-1548.

139. Jiao S, Meng F, Zhang J, Yang X, Zheng X, Wang L. STAT1 mediates cellular senescence induced by angiotensin II and $\mathrm{H}_{2} \mathrm{O}_{2}$ in human glomerular mesangial cells. Mol Cell Biochem. 2012;365(1-2):9-17.

140.Yu YC, et al. Radiation-induced senescence in securin-deficient cancer cells promotes cell invasion involving the IL-6/STAT3 and PDGF-BB/ PDGFR pathways. Sci Rep. 2013;3:1675.

141. Passos JF, et al. Feedback between p21 and reactive oxygen production is necessary for cell senescence. Mol Syst Biol. 2010;6:347.

142.Shiloh Y. ATM and related protein kinases: safeguarding genome integrity. Nat Rev Cancer. 2003;3(3):155-168.

143. Beauséjour CM, et al. Reversal of human cellular senescence: roles of the $\mathrm{p} 53$ and $\mathrm{p} 16$ pathways. EMBO J. 2003;22(16):4212-4222.

144.Davis T, et al. Synthesis and in vivo activity of MK2 and MK2 substrate-selective p38alpha(MAPK) inhibitors in Werner syndrome cells. Bioorg Med Chem Lett. 2007;17(24):6832-6835.

145. Ono K, Han J. The p38 signal transduction pathway: activation and function. Cell Signal. 2000;12(1):1-13. 
146.Flaherty KT, et al. Improved survival with MEK inhibition in BRAF-mutated melanoma. $N$ EnglJ Med. 2012;367(2):107-114.

147. Flaherty KT, et al. Combined BRAF and MEK inhibition in melanoma with BRAF V600 mutations. N Engl J Med. 2012;367(18):1694-1703.

148. Johnson DB, Sosman JA. Update on the targeted therapy of melanoma. Curr Treat Options Oncol. 2013;14(2):280-292.

149. Boni A, et al. Selective BRAFV600E inhibition enhances T-cell recognition of melanoma without affecting lymphocyte function. Cancer Res. 2010;70(13):5213-5219.

150. Frederick DT, et al. BRAF inhibition is associated with enhanced melanoma antigen expression and a more favorable tumor microenvironment in patients with metastatic melanoma. Clin Cancer Res. 2013;19(5):1225-1231.

151. Manic G, Obrist F, Sistigu A, Vitale I. Trial Watch: Targeting ATM-CHK2 and ATR-CHK1 pathways for anticancer therapy. Mol Cell Oncol. 2015;2(4):e1012976.

152. Bang YJ, et al. Randomized, double-blind phase II trial with prospective classification by ATM protein level to evaluate the efficacy and tolerability of olaparib plus paclitaxel in patients with recurrent or metastatic gastric cancer. J Clin Oncol. 2015;33(33):3858-3865.

153. Flaherty KT, et al. Improved survival with MEK inhibition in BRAF-mutated melanoma. $N$ EnglJ Med. 2012;367(2):107-114.

154. Hatzivassiliou G, et al. Mechanism of MEK inhibition determines efficacy in mutant KRAS- versus BRAF-driven cancers. Nature. 2013;501(7466):232-236.

155. Sutmuller RP, et al. Toll-like receptor 2 controls expansion and function of regulatory T cells. J Clin Invest. 2006;116(2):485-494.

156. Peng G, et al. Toll-like receptor 8-mediated reversal of CD4+ regulatory T cell function. Science. 2005;309(5739):1380-1384.

157. Peng G, Wang HY, Peng W, Kiniwa Y, Seo KH, Wang RF. Tumor-infiltrating gammadelta T cells suppress $\mathrm{T}$ and dendritic cell function via mecha- nisms controlled by a unique toll-like receptor signaling pathway. Immunity. 2007;27(2):334-348.

158. Huang L, Xu H, Peng G. TLR-mediated metabolic reprogramming in the tumor microenvironment: potential novel strategies for cancer immunotherapy. Cell Mol Immunol. 2018;15(5):428-437.

159. Pearce EL. Metabolism in T cell activation and differentiation. Curr Opin Immunol. 2010;22(3):314-320.

160.Zeng H, Chi H. Metabolic control of regulatory T cell development and function. Trends Immunol. 2015;36(1):3-12.

161. Newton R, Priyadharshini B, Turka LA. Immunometabolism of regulatory T cells. Nat Immunol. 2016;17(6):618-625.

162. MacIver NJ, Michalek RD, Rathmell JC. Metabolic regulation of T lymphocytes. Annu Rev Immunol. 2013;31:259-283.

163. Procaccini C, et al. The proteomic landscape of human ex vivo regulatory and conventional $\mathrm{T}$ cells reveals specific metabolic requirements. Immunity. 2016;44(2):406-421.

164. Shi H, Kokoeva MV, Inouye K, Tzameli I, Yin H, Flier JS. TLR4 links innate immunity and fatty acid-induced insulin resistance. J Clin Invest. 2006;116(11):3015-3025.

165. Huang S, et al. Saturated fatty acids activate TLR-mediated proinflammatory signaling pathways. J Lipid Res. 2012;53(9):2002-2013.

166. Lee JY, et al. Saturated fatty acid activates but polyunsaturated fatty acid inhibits Toll-like receptor 2 dimerized with Toll-like receptor 6 or 1. J Biol Chem. 2004;279(17):16971-16979.

167. Gerriets VA, et al. Foxp3 and Toll-like receptor signaling balance $\mathrm{T}_{\text {reg }}$ cell anabolic metabolism for suppression. Nat Immunol. 2016;17(12):1459-1466

168. Veyrat M, et al. Stimulation of the toll-like receptor 3 promotes metabolic reprogramming in head and neck carcinoma cells. Oncotarget. 2016;7(50):82580-82593.

169. Rosenberg SA, Restifo NP. Adoptive cell transfer as personalized immunotherapy for human cancer. Science. 2015;348(6230):62-68.

170.Thommen DS, Schumacher TN. T cell dysfunc- tion in cancer. Cancer Cell. 2018;33(4):547-562.

171. Zou W, Wolchok JD, Chen L. PD-L1 (B7-H1)

and PD-1 pathway blockade for cancer therapy: mechanisms, response biomarkers, and combinations. Sci Transl Med. 2016;8(328):328rv4.

172. Schreiber RD, Old LJ, Smyth MJ. Cancer immunoediting: integrating immunity's roles in cancer suppression and promotion. Science. 2011;331(6024):1565-1570.

173. Bui JD, Schreiber RD. Cancer immunosurveillance, immunoediting and inflammation: independent or interdependent processes? Curr Opin Immunol. 2007;19(2):203-208.

174. Huang Y, et al. CD $4^{+}$and $C D 8^{+} \mathrm{T}$ cells have opposing roles in breast cancer progression and outcome. Oncotarget. 2015;6(19):17462-17478.

175. Spranger S. Mechanisms of tumor escape in the context of the T-cell-inflamed and the non-Tcell-inflamed tumor microenvironment. Int Immunol. 2016;28(8):383-391.

176. Denkert C, et al. Tumour-infiltrating lymphocytes and prognosis in different subtypes of breast cancer: a pooled analysis of 3771 patients treated with neoadjuvant therapy. Lancet Oncol. 2018;19(1):40-50.

177. Wargo JA, Reddy SM, Reuben A, Sharma P. Monitoring immune responses in the tumor microenvironment. Curr Opin Immunol. 2016;41:23-31.

178. Lu YC, Jia L, Zheng Z, Tran E, Robbins PF, Rosenberg SA. Single-cell transcriptome analysis reveals gene signatures associated with $\mathrm{T}$-cell persistence following adoptive cell therapy. Cancer Immunol Res. 2019;7(11):1824-1836.

179. Takasugi M, Okada R, Takahashi A, Virya Chen D, Watanabe S, Hara E. Small extracellular vesicles secreted from senescent cells promote cancer cell proliferation through EphA2. Nat Commun. 2017;8:15729.

180. Hui E, et al. T cell costimulatory receptor CD28 is a primary target for PD-1-mediated inhibition. Science. 2017;355(6332):1428-1433.

181. Kamphorst AO, et al. Rescue of exhausted CD8 T cells by PD-1-targeted therapies is CD28-dependent. Science. 2017;355(6332):1423-1427. 